CORRECTION OPEN

\title{
Correction to: Towards a fine-scale picture of European genetic diversity
}

\author{
Michael Nothnagel (iD) \\ (c) The Author(s), under exclusive licence to European Society of Human Genetics 2021
}

European Journal of Human Genetics (2022) 30:249; https://doi.org/10.1038/s41431-021-00949-z

Correction to:

European Journal of Human Genetics https://doi.org/10.1038/ s41431-020-0620-1, published online 01 April 2020

The article "Towards a fine-scale picture of European genetic diversity", written by Michael Nothnagel, was originally published electronically on the publisher's internet portal on 1 April 2020 without open access. With the author' decision to opt for Open Choice the copyright of the article changed on 4 August 2021 to $(?$ Author(s) 2020 and the article is forthwith distributed under a Creative Commons Attribution 4.0 International License, which permits use, sharing, adaptation, distribution and reproduction in any medium or format, as long as you give appropriate credit to the original author(s) and the source, provide a link to the Creative Commons licence, and indicate if changes were made. The images or other third party material in this article are included in the article's Creative Commons licence, unless indicated otherwise in a credit line to the material. If material is not included in the article's Creative Commons licence and your intended use is not permitted by statutory regulation or exceeds the permitted use, you will need to obtain permission directly from the copyright holder. To view a copy of this licence, visit http://creativecommons.org/ licenses/by/4.0.

The original article has been corrected.

\begin{abstract}
(c) (i)
Open Access This article is licensed under a Creative Commons Attribution 4.0 International License, which permits use, sharing, adaptation, distribution and reproduction in any medium or format, as long as you give appropriate credit to the original author(s) and the source, provide a link to the Creative Commons license, and indicate if changes were made. The images or other third party material in this article are included in the article's Creative Commons license, unless indicated otherwise in a credit line to the material. If material is not included in the article's Creative Commons license and your intended use is not permitted by statutory regulation or exceeds the permitted use, you will need to obtain permission directly from the copyright holder. To view a copy of this license, visit http://creativecommons. org/licenses/by/4.0/.
\end{abstract}

(c) The Author(s), under exclusive licence to European Society of Human Genetics 2021 